\title{
Virological Predictors of Response to Retreatment in Hepatitis C Genotype 2 Infected Patients
}

\author{
Chung-Feng Huang ${ }^{1,2,3}$, Chia-Yen Dai ${ }^{2,4,5 *}$, Ming-Lun Yeh $^{2}$, Jee-Fu Huang ${ }^{2,5,6}$, Ching-I Huang ${ }^{7}$, Ming- \\ Yen Hsieh" ${ }^{7}$, Zu-Yau Lin ${ }^{2,5}$, Shinn-Cherng Chen ${ }^{2,5}$, Liang-Yen Wang ${ }^{2,5}$, Suh-Hang Hank Juo ${ }^{8}$, Wan- \\ Long Chuang ${ }^{2,5}$, Yi-Ching Lin ${ }^{1,9}$, Ming-Lung $\mathrm{Yu}^{2,5}$
}

1 Institute of Clinical Medicine, College of Medicine, Kaohsiung Medical University, Kaohsiung, Taiwan, 2 Hepatobiliary Division, Department of Internal Medicine, Kaohsiung Medical University Hospital, Kaohsiung, Taiwan, 3 Department of Occupational Medicine, Kaohsiung Municipal Ta-Tung Hospital, Kaohsiung Medical University Hospital, Kaohsiung Medical University, Kaohsiung, Taiwan, 4 Department of Preventive Medicine, Kaohsiung Medical University Hospital, Kaohsiung, Taiwan, $\mathbf{5}$ Faculty of Internal Medicine, College of Medicine, Kaohsiung Medical University, Kaohsiung, Taiwan, 6 Department of Internal Medicine, Kaohsiung Municipal Hsiao-Kang Hospital, Kaohsiung Medical University Hospital, Kaohsiung, Taiwan, 7 Department of Internal Medicine, Kaohsiung Municipal Ta-Tung Hospital, Kaohsiung Medical University Hospital, Kaohsiung Medical University, Kaohsiung, Taiwan, 8 Department of Medical Genetics, Kaohsiung Medical University, Kaohsiung, Taiwan, 9 Department of Laboratory Medicine, Kaohsiung Medical University Hospital, Kaohsiung Medical University, Kaohsiung, Taiwan

\begin{abstract}
Background/Aims: The impact of virological factors and interleukin-28B (IL-28B) genetic variants on retreatment of hepatitis $\mathrm{C}$ virus genotype 2 (HCV-2) treatment-experienced patients remains unknown.

Methods: On-treatment virological responses and IL-28B rs8099917 genotype were determined in 46 HCV-2 treatmentexperienced patients (42 previous relapsers; four previous non-responders) retreated with 24-week peginterferon/ribavirin.

Results: Forty (87.0\%) patients carried the rs8099917 TT genotype and 6 patients (13.0\%) carried the TG/GG genotype. The sustained virological response (SVR; seronegativity of HCV RNA throughout 24 weeks of the post-treatment follow-up period) rate was $71.7 \%$. Compared with previous non-responders, previous relapsers had a significantly higher SVR rate $(78.6 \%$ vs. $0 \%, \mathrm{P}=0.004)$ and a lower relapse rate $(17.5 \%$ vs. $100 \%, \mathrm{P}=0.04)$. All the previous non-responders were with the rs8099917 TT genotype. As for those who relapsed, treatment responses, including the rates of rapid virological response (RVR, $80.6 \%$ vs. $66.7 \%, P=0.59$ ), early virological response (EVR, 97.2\% vs. $83.3 \%, P=0.27$ ), end-of-treatment virological response $(97.2 \%$ vs. $83.3 \%, P=0.27)$ and SVR $(80.6 \%$ vs. $66.7 \%, P=0.59)$ and relapse rate $(17.1 \%$ vs. $20.0 \%, P=1)$ did not differ significantly between patients with the rs8099917 $\Pi$ and those with the non- $\Pi$ genotype. Multivariate analysis revealed that the most important factor predictive of an SVR in the retreatment of HCV-2 was previous relapse; the only factor predictive of an SVR for previous relapsers was the achievement of an EVR. Compared with the achievement of a RVR, the attainment of an EVR was more accurate in predicting an SVR ( $88 \%$ vs. $74 \%$ ).
\end{abstract}

Conclusions: Peginterferon/ribavirin is effective in the retreatment of HCV-2 relapsers, especially among those who achieved an EVR.

Citation: Huang C-F, Dai C-Y, Yeh M-L, Huang J-F, Huang C-I, et al. (2013) Virological Predictors of Response to Retreatment in Hepatitis C Genotype 2 Infected Patients. PLoS ONE 8(3): e58882. doi:10.1371/journal.pone.0058882

Editor: Erica Villa, University of Modena \& Reggio Emilia, Italy

Received November 13, 2012; Accepted February 7, 2013; Published March 19, 2013

Copyright: (c) 2013 Huang et al. This is an open-access article distributed under the terms of the Creative Commons Attribution License, which permits unrestricted use, distribution, and reproduction in any medium, provided the original author and source are credited.

Funding: This study was supported by a grant from the Kaohsiung Medical University Hospital (KMUH100-9102) and a grant from the National Science Council, Taiwan (NSC 100-2314-B-037 -014-MY2). The funders had no role in the study design, data collection and analysis, decision to publish, or preparation of the manuscript.

Competing Interests: The authors have read the journal's policy and have the following conflicts: co-author Ming-Lung Yu is the member of advisory board of Merck Sharp \& Dohme (MSD), Roche and Abbott and on the PLOS editorial board. This does not alter the authors' adherence to all the PLOS ONE policies on sharing data and materials.

*E-mail: fish6069@gmail.com

\section{Introduction}

Hepatitis $\mathrm{G}$ virus (HCV) infection is one of the leading threats to public health in Taiwan and worldwide. [1] Carriers might develop hepatocarcinogenesis and liver-related morbidity and mortality if left untreated. Successful HCV treatment using antiviral therapy would prevent the consequences of HCV infection. [2,3] Recently, the introduction of direct antiviral agents (DAA) has greatly improved the sustained virological response (SVR) rate in patients with HCV genotype 1 (HCV-1) infection. [4] On the other hand, pegylated interferon (peginterferon)/ribavirin, which is the standard-of-care for HCV-2 patients, has provided satisfactory results with an SVR rate of 80-93\%.[5-7] As a consequence, only a minority of HCV-2 patients fail antiviral therapy and are prone to be neglected because of the excellent treatment efficacy toward HCV-2 infection. It is noteworthy that these patients are still at high risk for liver disease progression and hepatocarcinogenesis. $[2,3,8]$ Therefore, the issue of retreatment of HCV-2 patients who have failed previous treatments is important. However, it has 
rarely been addressed, which may reflect the limited number of patients in this specific scenario.

Recent studies have provided solid evidence that host interleukin 28B (IL-28B) genetic polymorphisms are associated with treatment efficacy in HCV-1 patients treated with peginterferon/ ribavirin.[9-11] However, the application of DAAs seems to attenuate the role of host IL-28B genetic variants in HCV-1 infection. [12] On the other hand, results regarding the role of IL$28 \mathrm{~B}$ in HCV-2 patients seem contradictory. Furthermore, the impact on viral kinetics was also inconsistent across studies. [1315] A recent meta-analysis showed that favorable IL-28B polymorphisms were associated with a higher sustained virological response rate (SVR), but the effect was too limited to justify a clinical treatment decision. [16] It is noteworthy that the impact of host Il-28B genetic variants on HCV-2 treatment experienced patients with has never been explored. The current study aimed to elucidate the efficacy of HCV-2 patients retreated with 24-week peginterferon/ribavirin combination therapy. We also assessed the potential impact of host IL-28B genetic variants on a wellcharacterized Asian patient cohort.

\section{Methods}

\section{Patients}

Patients were recruited consecutively from one medical center and 2 regional core hospitals from 2002 to 2009 if they had relapsed (defined as HCV RNA seronegativity at the end of therapy but reappearance of viremia during follow-up) or if they were non-responders (defined as the presence of HCV RNA at the end of the prior course of therapy) to previous interferon-based therapy. The previous treatment course comprised conventional interferon at a dose of 3-6 million units thrice weekly or peginterferon alpha-2a (180 $\mu \mathrm{g} /$ week) or peginterferon alpha-2b $(1.5 \mu \mathrm{g} / \mathrm{kg} /$ week) plus ribavirin for 24 weeks from the cohort that has been intervened previously.[13] Patients were excluded if they had any of the following: any other coexistent liver disorders (alcoholic liver disease, autoimmune hepatitis, primary biliary cirrhosis, sclerosing cholangitis, Wilson's disease and $\alpha_{1}$-antitrypsin deficiency); co-infection with hepatitis B or anti-human immunodeficiency virus; active use of illicit intravenous drugs; or a history of an uncontrolled psychiatric condition, pregnancy, decompensated cirrhosis or overt hepatic failure. All of the participants were retreated either with peginterferon alpha-2a (180 $\mu \mathrm{g} /$ week) or with peginterferon alpha-2b $(1.5 \mu \mathrm{g} / \mathrm{kg} /$ week $)$ plus weight-based ribavirin $(1000 \mathrm{mg} / \mathrm{d}$ for a weight of $<75 \mathrm{~kg}$ and $1200 \mathrm{mg} / \mathrm{d}$ for a weight of $>75 \mathrm{~kg}$ ) for 24 weeks. Serum HCV RNA was obtained using real-time polymerase chain reaction (RealTime HCV; Abbott Molecular, Des Plaines ILUSA, lower limit of quantitation $<12 \mathrm{IU} / \mathrm{mL}$ ) at baseline, treatment weeks 4 and 12, the end-oftreatment and 24 weeks after therapy.[17] All of the patients provided written informed consent before enrollment. The institutional review board at Kaohsiung Medical University Hospital approved the protocol, which conformed to the guidelines of the International Conference on Harmonization for Good Clinical Practice.

\section{Assessment of efficacy}

A rapid virological response (RVR) was defined as seronegativity of HCV RNA at week 4 of treatment. An EVR was defined as a seronegative or at least a $2-\log _{10}$ decrease from baseline in the serum HCV RNA at week 12 of treatment. An end-of-treatment virological response (EOTVR) was defined as seronegativity of HCV RNA at the end of treatment. The endpoint of the study was the achievement of a sustained virological response (SVR), which was defined as seronegativity of HCV RNA throughout 24 weeks of the post-treatment follow-up period.

\section{IL-28B genotyping and statistical analyses}

Rs8099917 was selected as the candidate single-nucleotide polymorphism (SNP) in the current study. Genetic testing of IL28B rs8099917 was determined using methods that have been previously described.[10,13] The frequency was compared between groups using the $\chi^{2}$ test and a Yates correction or a Fisher exact test. Group means and standard deviations were compared using an analysis of variance test and the Student's $t$ test or the Mann-Whitney U test. Serum HCV RNA levels were expressed after logarithmic transformation of the original values. The aspartate aminotransferase (AST)-to-platelet ratio index (APRI) was calculated using the following equation: (AST level/ upper limit of normal range)/platelet counts $\left(10^{9} / \mathrm{L}\right) \times 100$. The APRI was used to reflect the severity of liver fibrosis. [18] The frequency of the rare allele $(\mathrm{G})$ of the rs8099917 genotype was too low; thus, the rare homozygote (GG) and heterozygote (GT) genotypes were combined together when analyzing the SNP. To assess the relative contribution of the predictors of a RVR, a multivariable model was applied with age, sex, body weight, baseline HCV RNA levels, APRI, previous treatment regimen (optimal or suboptimal), previous virological response (relapse or non-response) and rs8099917 genotype as covariants. In addition to the above-mentioned variables, the achievement of a RVR and an EVR were taken into consideration while assessing determinants predictive of an SVR. The statistical analyses were performed using the SPSS 12.0 statistical package (SPSS, Chicago, IL, USA). All statistical analyses were based on two-sided hypothesis tests with a significance level of $\mathrm{p}<0.05$.

\section{Results}

\section{Patient profile}

A total of 46 patients were recruited in this study. The basic demographic, virological, and clinical features of the patients were shown in table 1 . Forty (87.0\%) patients carried the rs8099917 TT genotype and $6(13.0 \%)$ patients carried the rs8099917 TG/GG genotype. As for the previous virological response and treatment regimen, forty-two $(91.3 \%)$ patients were previous relapsers and 4 $(8.7 \%)$ patients were previous virological non-responders. The basic demographic, virological, and clinical features did not differ significantly between previous relapsers and non-responders. Fifteen $(33 \%)$ patients previously received conventional interferon/ribavirin, and the remaining 31 (67\%) patients received 24week peginterferon/ribavirin combination therapy.

\section{Virological responses and factors associated with RVR and SVR}

The rates of RVR, EVR, EOTVR, SVR and relapse were $76.1 \%, 93.5 \%, 91.3 \%, 71.7 \%$ and $21.4 \%$, respectively. The rates of RVR $(78.6 \%$ vs. $50.0 \%, P=0.24)$ and $\operatorname{EVR}(95.2 \%$ vs. $75.0 \%$, $\mathrm{P}=0.24)$ were not significantly different between relapsers and non-responders. However, compared with non-responders, relapsers had significantly higher rates of EOTVR $(95.2 \%$ vs. $50.0 \%$, $\mathrm{P}=0.03)$ and $\operatorname{SVR}(78.6 \%$ vs. $0 \%, \mathrm{P}=0.004)$ and a lower relapse rate $(17.5 \%$ vs. $100 \%, \mathrm{P}=0.04)$. As shown in table 2 , neither any baseline factor including host IL-28B genotype nor previous virological response was significantly associated with a higher RVR rate. Lower baseline HCV RNA levels, previous virological relapse and the achievement of a RVR and an EVR were factors that were significantly associated with an SVR in the univariate analysis (table 2). Multivariate analysis revealed that the only 
Table 1. Basic demographic, virological, and clinical features of HCV genotype 2 patients who failed interferon-based therapy.

\begin{tabular}{|c|c|c|c|c|}
\hline & All patients $(\mathrm{N}=46)$ & Relapsers $(\mathrm{N}=\mathbf{4 2})$ & Non-responders $(\mathrm{N}=4)$ & $P$ value \\
\hline Age, years, mean(SD) & $58.6(9.6)$ & $58.6(10.0)$ & $58.0(4.2)$ & 0.90 \\
\hline Male, n (\%) & $25(54.3)$ & $23(54.8)$ & $2(50.0)$ & 1 \\
\hline Body weight, kg, mean (SD) & $64.2(8.6)$ & $63.7(8.9)$ & $69.1(1.7)$ & 0.15 \\
\hline Baseline HCV RNA, log IU/ml, mean (SD) & $5.45(0.81)$ & $5.39(0.81)$ & $5.99(0.60)$ & 0.16 \\
\hline Baseline HCV RNA > 400,000 IU/mL, n (\%) & $23(50.0)$ & $20(47.6)$ & $3(75.0)$ & 0.61 \\
\hline APRI, mean (SD) & $2.05(1.55)$ & $1.99(1.44)$ & $2.60(2.69)$ & 0.46 \\
\hline AST, IU/I, mean (SD) & $108.6(73.9)$ & $108.8(75.9)$ & $106.8(57.3)$ & 0.96 \\
\hline ALT, IU/I, mean (SD) & $159.9(130.6)$ & $164.3(135.5)$ & $113.8(41.3)$ & 0.47 \\
\hline Rs8099917 TT genotype, n (\%) & $40(87.0)$ & $36(85.7)$ & $4(100)$ & 1 \\
\hline Previous optimal treatment regimen*, n (\%) & $31(67.4)$ & $28(66.7)$ & $3(75.0)$ & 1 \\
\hline
\end{tabular}

Note: SD: standard deviation; AST: aspartate aminotransferase; ALT: alanine aminotransferase; APRI: aspartate aminotransferase-to-platelet ratio index. ${ }^{*}$ defined as patients who had received 24 weeks of peginterferon/ribavirin

doi:10.1371/journal.pone.0058882.t001

factor predictive of an SVR was previous relapse (table 3). Among patients who previously relapsed, the SVR rate was substantially higher in patients with an RVR and significantly higher in patients achieving an EVR compared with their counterparts (table 4). Multivariate analysis revealed that the only factor predictive of an SVR for previous relapsers was the achievement of an EVR (table 3).

\section{On-treatment responses in predicting treatment outcome}

Because the achievement of an EVR, but not a RVR, was independently predictive of treatment outcome among relapsers, we further analyzed the accuracy of the two on-treatment factors in predicting an SVR. As shown in table 5, the achievement of an
EVR provided a negative predictive value of $100 \%$. The positive predictive value for an SVR was similar between patients with a RVR (80\% for all patients and 85\% for relapsers) and an EVR (77\% for all patients and $83 \%$ for relapsers). The achievement of an EVR provided a better accuracy in predicting an SVR $(88 \%$ for all patients and $83 \%$ for relapsers) compared to the factor of a RVR (74\% for all patients and 75\% for relapsers).

\section{Influence of IL-28B genetic variants on treatment responses}

Treatment responses including rates of RVR $(77.5 \%$ vs. $66.7 \%$, $\mathrm{P}=0.62)$, EVR $(95.0 \%$ vs. $83.3 \%, \mathrm{P}=0.35)$, EOTVR $(92.3 \%$ vs. $83.3 \%, \mathrm{P}=0.44)$ and $\operatorname{SVR}(72.5 \%$ vs. $66.7 \%, \mathrm{P}=1)$ and relapse rate $(21.6 \%$ vs. $20.0 \%, \mathrm{P}=1)$ were similar between patients with

Table 2. Univariate analysis of factors associated with rapid virological response and sustained virological response.

\begin{tabular}{|c|c|c|c|c|c|c|}
\hline & $\operatorname{RVR}(+)(n=35)$ & $\operatorname{RVR}(-)(n=11)$ & $P$ value & SVR (+) & SVR(-) & $P$ value \\
\hline & & & & $(n=33)$ & $(n=13)$ & \\
\hline Rs8099917 TT genotype, n (\%) & 31 (88.6) & $9(81.8)$ & 0.62 & $29(87.9)$ & $11(84.6)$ & 1 \\
\hline Male sex, $\mathrm{n}(\%)$ & $20(57.1)$ & $5(45.5)$ & 0.50 & $18(54.5)$ & $7(53.8)$ & 0.97 \\
\hline Age (yrs, mean(SD)) & $57.9(10.3)$ & $60.7(6.9)$ & 0.40 & $57.7(10.4)$ & $60.9(7.0)$ & 0.32 \\
\hline Body weight, kg, mean (SD) & $63.4(9.0)$ & $66.7(7.2)$ & 0.26 & $63.9(8.6)$ & $64.8(9.0)$ & 0.74 \\
\hline Baseline HCV RNA (log IU/ml, mean(SD)) & $5.37(0.82)$ & $5.70(0.78)$ & 0.24 & $5.29(0.82)$ & $5.84(0.67)$ & 0.04 \\
\hline Baseline HCV RNA > 400,000 IU/mL, n (\%) & $16(45.7)$ & $7(63.6)$ & 0.49 & $15(45.5)$ & $8(61.5)$ & 0.33 \\
\hline APRI, mean (SD) & $2.02(1.43)$ & $2.14(1.95)$ & 0.83 & $2.04(1.49)$ & $2.05(1.75)$ & 0.98 \\
\hline AST (IU/l, mean (SD)) & $112.1(78.0)$ & $97.6(61.1)$ & 0.58 & $111.4(78.6)$ & $101.6(62.8)$ & 0.69 \\
\hline ALT (IU/l, mean (SD)) & $174.0(141.0)$ & $115.2(78.9)$ & 0.20 & $169.1(141.3)$ & $136.6(99.5)$ & 0.45 \\
\hline $\begin{array}{l}\text { Virological responses of previous antiviral therapy, } n \\
\text { (\%) }\end{array}$ & & & 0.24 & & & 0.004 \\
\hline Previous relapse & $33(94.3)$ & $9(81.8)$ & & $33(100)$ & $9(69.2)$ & \\
\hline Previous null responder & $2(5.7)$ & $2(18.2)$ & & $0(0)$ & $4(30.8)$ & \\
\hline Previous optimal treatment regimen*, n (\%) & $20(57.1)$ & $10(90.9)$ & 0.07 & $20(60.6)$ & 11 (84.6) & 0.17 \\
\hline RVR (+), n (\%) & - & - & - & $28(84.8)$ & 7 (53.8) & 0.05 \\
\hline EVR (+), n (\%) & - & - & - & $33(100)$ & $10(76.9)$ & 0.02 \\
\hline
\end{tabular}

Note: SD: standard deviation; SVR: sustained virological response; RVR: rapid virological response; EVR, early virological response. AST: aspartate aminotransferase; ALT: alanine aminotransferase; APRI: aspartate aminotransferase-to-platelet ratio index.* defined as patients who had received 24 weeks of peginterferon/ribavirin doi:10.1371/journal.pone.0058882.t002 
Table 3. Logistic regression analysis of factors associated with sustained virological response in all patients and relapsers.

\begin{tabular}{llll}
\hline & $\begin{array}{l}\text { Odds } \\
\text { Ratio }\end{array}$ & $\begin{array}{l}\mathbf{9 5 \%} \text { Confidence } \\
\text { Intervals }\end{array}$ & $\boldsymbol{P}$ value \\
\hline Variables & 1 & & \\
\hline $\begin{array}{l}\text { All patients } \\
\text { Relapsers }\end{array}$ & 0.000 & $<0.0001$ \\
$\begin{array}{l}\text { Non-responders } \\
\text { Relapsers }\end{array}$ & 1 & \\
$\begin{array}{l}\text { EVR } \\
\text { Non-EVR }\end{array}$ & 0.000 & \\
\hline $\begin{array}{l}\text { Note: EVR: early virological response. } \\
\text { doi:10.1371/journal.pone.0058882.t003 }\end{array}$ &
\end{tabular}

the TT or non-TT genotype (fig 1). All the 4 non-responders were with rs8099917 TT genotype. Treatment responses including rates of RVR (80.6\% vs. $66.7 \%, \mathrm{P}=0.59)$, EVR (97.2\% vs. $83.3 \%$, $\mathrm{P}=0.27)$, EOTVR $(97.2 \%$ vs. $83.3 \%, \mathrm{P}=0.27)$ and SVR $(80.6 \%$ vs. $66.7 \%, \mathrm{P}=0.59)$ and relapse rate $(17.1 \%$ vs. $20.0 \%, \mathrm{P}=1) \mathrm{did}$ not differ significantly between previous relapsers with rs8099917 TT or non-TT genotype.

\section{Discussion}

In the era of DAA, 24 weeks of pegylated interferon plus ribavirin treatment remains the standard of care for $\mathrm{HCV}-2$ infected patients [19,20] with an SVR rate of 90\%. [5,21] As a result, studies involving $\mathrm{HCV}-2$ treatment experienced patients with were scarce, and majority of the results were linked to other HCV genotypes as a subgroup analysis. [22-28] To the best of our knowledge, this is the first report that focused on previously treated patients with $\mathrm{HCV}-2$ and explored the possible role of viral factors and host IL-28B genetic polymorphisms in the retreatment outcome. We noted that previous virological response was the most critical factor predictive of treatment success. Four-fifths of the patients who previously relapsed, but none of the nonresponders, had an SVR after 24 weeks of peginterferon/ribavirin retreatment. On treatment viral kinetics rather than host IL-28B genetic variants might play a role in determining an SVR in relapsers.

Although only a minority of $\mathrm{HCV}-2$ patients failed to eradicate virus after 24 weeks of standard-of-care, these patients remained at a great risk of liver disease progression.[2,29] However, standard strategies toward treatment-experienced $\mathrm{HCV}-2$ patients has not been clearly setup. Discordant results regarding HCV-1 retreatment by interferon-based therapy have been observed across studies.[30] Similarly, an SVR rate of ranging from 31\% to $79 \%$ has been reported in small-scale studies of HCV-2 retreatment (table 6). [22-28] The divergent reports might be attributed to the limited sample size and the diverse patient characteristics. A variety of previous and current treatment regimens might also account for the inconclusive results. Basso et al.[23] has reported an SVR rate of $78.6 \%$ in previous relapsers, in which study patients who failed to eradicate HCV infection by conventional interferon (3 MU thrice weekly)/ribavirin were retreated with suboptimal pegylated interferon alpha- $2 \mathrm{~b}(1 \mu \mathrm{g} / \mathrm{kg} /$ week $)$ plus ribavirin (800-1200 mg/day) for 24 weeks. In the current study, we demonstrated a similar SVR rate for previous relapsers retreated with 24 weeks of peginterferon/weight-based ribavirin. The treatment efficacy remained consistent irrespective of the previous treatment regimen. The finding might provide more insight for clinicians in daily practice because pegylated interferon/ribavirin has been the standard of care for a decade, and most of the HCV-2 treatment experienced patients nowadays might have received an optimal regimen previously. It raised the issue that extending therapy to 48 weeks might be beneficial for certain treatment naive patients with unfavorable early viral kinetics and researches that identify the potential candidates for prolonged treatment remain elusive.[19]

A common finding in studies regarding $\mathrm{HCV}-1$ retreatment was that compared with previous relapsers, non-responders had significantly worse retreatment outcomes. [30] However, this was not always the case in HCV-2 studies. Jacobson et al. [25] reported an SVR of $5 \%$ for non-responders who received 48 weeks of pegylated interferon alpha- $2 \mathrm{~b}(1.0-1.5 \mu \mathrm{g} / \mathrm{kg} /$ week $)$ plus ribavirin (800-1200 mg/day) combination therapy. On the contrary, an SVR rate of $57-65 \%$ for non-responders has been reported by other studies. $[26,28]$ None of the non-responders in

Table 4. Univariate analysis of factors associated with sustained virological response in previous relapsers.

\begin{tabular}{llll}
\hline & & & \\
\hline & SVR (+) (n= 33) & SVR(-) (n=9) & P value \\
\hline Rs8099917 TT genotype, $\mathrm{n}(\%)$ & $29(87.9)$ & $7(77.8)$ & 0.59 \\
Male sex, $\mathrm{n}(\%)$ & $18(54.5)$ & $5(55.6)$ & 1 \\
Age (yrs, mean(SD)) & $57.7(10.4)$ & $62.1(7.8)$ & 0.24 \\
Body weight, kg, mean (SD) & $63.9(8.6)$ & $62.9(10.4)$ & 0.78 \\
Baseline HCV RNA (log IU/ml, mean(SD)) & $5.29(0.82)$ & $5.78(0.73)$ & 0.11 \\
Baseline HCV RNA > 400,000 IU/mL, $\mathrm{n}(\%)$ & $15(45.5)$ & $5(55.6)$ & 0.71 \\
APRI, mean (SD) & $2.04(1.49)$ & $1.81(1.29)$ & 0.67 \\
AST (IU/l, mean (SD)) & $111.4(78.6)$ & $99.3(68.4)$ & 0.68 \\
ALT (IU/l, mean (SD)) & $169.1(141.3)$ & $146.8(117.6)$ & 0.67 \\
Previous optimal treatment regimen*, $\mathrm{n}(\%)$ & $20(60.6)$ & $8(88.9)$ & 0.23 \\
RVR (+), $\mathrm{n}(\%)$ & $28(84.8)$ & $5(55.6)$ & 0.08 \\
EVR (+), $\mathrm{n}(\%)$ & $33(100)$ & $7(77.8)$ & 0.04 \\
\hline
\end{tabular}

Note: SD: standard deviation; SVR: sustained virological response; RVR: rapid virological response; EVR, early virological response. AST: aspartate aminotransferase; ALT: alanine aminotransferase; APRI: aspartate aminotransferase-to-platelet ratio index.* defined as patients who had received 24 weeks of peginterferon/ribavirin.

doi:10.1371/journal.pone.0058882.t004 
Table 5. Accuracy of the achievement of a RVR and an EVR in predicting an SVR.

\begin{tabular}{|c|c|c|c|c|c|c|c|c|}
\hline \multirow{2}{*}{ On treatment response } & \multirow{2}{*}{$\begin{array}{l}\text { SVR(+) } \\
\text { n (\%) }\end{array}$} & \multirow{2}{*}{$\frac{\text { SVR(-) }}{\text { n (\%) }}$} & \multirow[t]{2}{*}{$P$ value } & \multirow{2}{*}{$\begin{array}{l}\text { SEN } \\
\%\end{array}$} & \multirow{2}{*}{$\begin{array}{l}\text { SPE } \\
\%\end{array}$} & \multirow{2}{*}{$\frac{\text { PPV }}{\%}$} & \multirow{2}{*}{$\begin{array}{l}\text { NPV } \\
\%\end{array}$} & \multirow{2}{*}{$\begin{array}{l}\text { ACC } \\
\%\end{array}$} \\
\hline & & & & & & & & \\
\hline All patients & $\mathrm{n}=33$ & $n=13$ & & & & & & \\
\hline RVR (+) & $28(85)$ & 7 (54) & 0.05 & 85 & 46 & 80 & 55 & 74 \\
\hline EVR (+) & $33(100)$ & $10(77)$ & 0.02 & 100 & 23 & 77 & 100 & 88 \\
\hline Previous Relapsers & $\mathrm{n}=33$ & $n=9$ & & & & & & \\
\hline RVR (+) & $28(85)$ & $5(56)$ & 0.08 & 85 & 44 & 85 & 44 & 75 \\
\hline EVR (+) & $33(100)$ & $7(78)$ & 0.04 & 100 & 22 & 83 & 100 & 83 \\
\hline Previous Non-responders & $\mathrm{n}=0$ & $\mathrm{n}=4$ & & & & & & \\
\hline RVR (+) & - & $2(50)$ & - & - & 50 & - & 100 & - \\
\hline EVR (+) & - & $3(75)$ & - & - & 25 & - & 100 & - \\
\hline
\end{tabular}

Note: SVR: sustained virological response; RVR: rapid virological response; EVR, early virological response

doi:10.1371/journal.pone.0058882.t005

our study had an SVR. However, the sample size was too small for the results to be conclusive. Recently developed DAAs have become the standard of care for HCV-1 infection. [4] This innovation, in conjunction with peginterferon and ribavirin, substantially improved the treatment efficacy in treatment-naïve and -experienced HCV-1 patients. Nevertheless, the development of small molecules against $\mathrm{HCV}-2 / 3$ remains in its early stages. $[31,32]$ The strategy of extending the retreatment duration $[24,26]$ or applying DAAs to the difficult-to-treat population on the basis of cost-effectiveness [33] requires further exploration.

Emerging data have demonstrated that favorable host IL-28B genetic variants have been associated with a higher SVR rate in HCV-1 patients.[9-11] In contrast, results regarding the role of IL-28B in HCV-2 patients were conflicting.[13-15] A recent meta-analysis has shown that favorable IL-28B polymorphisms increase the SVR rate by $5 \%$, but the predictive value was limited compared to other predictive factors.[16] In addition, the impact

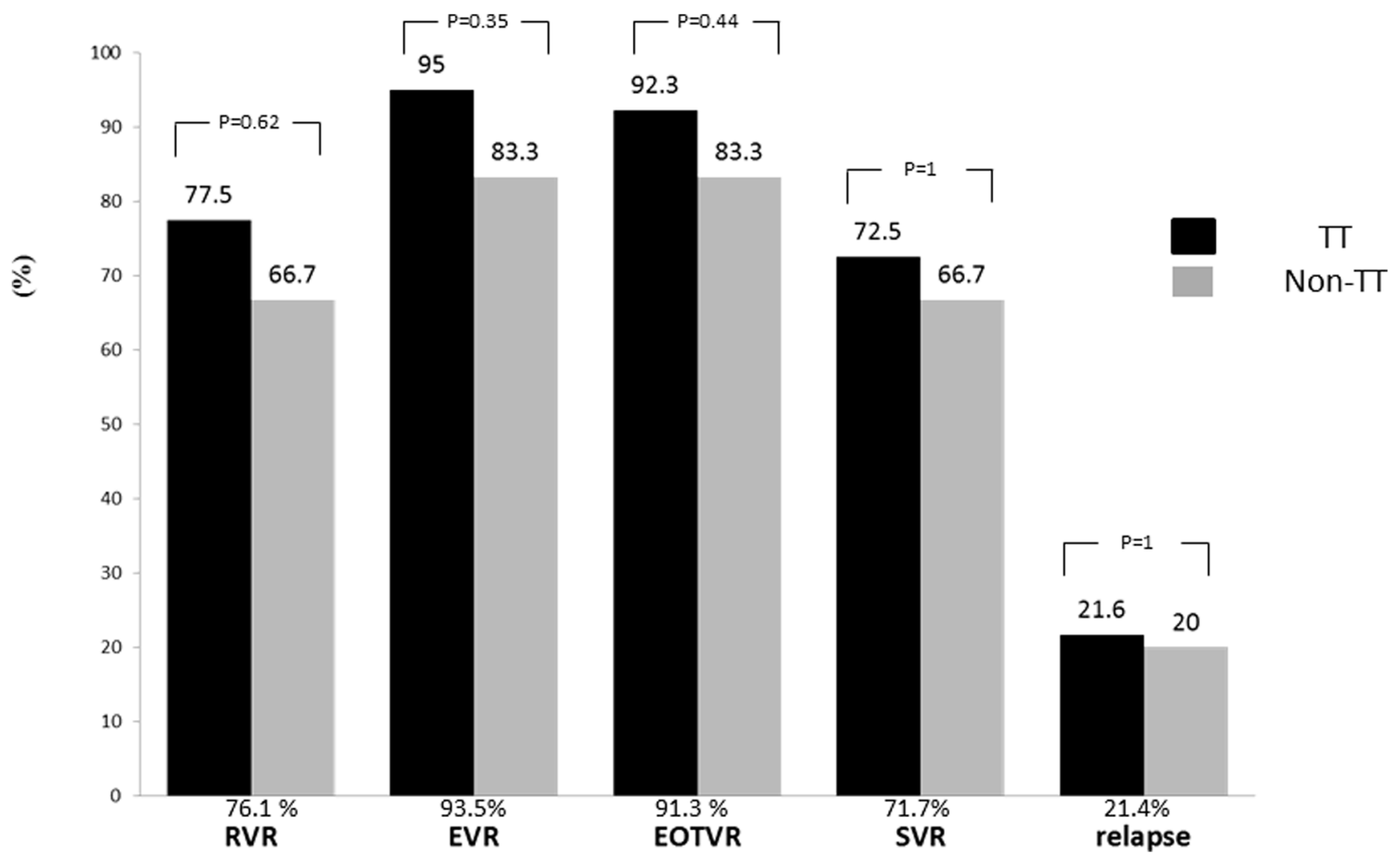

Figure 1. Treatment responses between patients with different rs8099917 genotypes. Black bar represents patients with rs8099917 $T T$ genotype. Brown bar represents patients with rs 8099917 GT/GG genotype. RVR, rapid virological response. EVR, early virological response. EOTVR, end of treatment virological response. SVR, sustained virological response.

doi:10.1371/journal.pone.0058882.g001 
Table 6. Studies regarding HCV genotype 2 retreatment with pegylated interferon plus ribavirin.

\begin{tabular}{|c|c|c|c|c|c|}
\hline & Case No & Regimen & $\begin{array}{l}\text { Previous virological } \\
\text { response }\end{array}$ & SVR rate & Reference \\
\hline Shiffman et al., 2004 & 31 & $\begin{array}{l}\text { pegylated interferon alfa-2a ( } 180 \mu \mathrm{g} / \text { week) plus } \\
\text { ribavirin }(1000-1200 \mathrm{mg} / \text { day }) \text { for } 48 \text { weeks }\end{array}$ & $\begin{array}{l}\text { non-responders with } \\
\text { advanced fibrosis }\end{array}$ & $65 \%$ & [24] \\
\hline Jacobson et al.,2005 & $26^{*}$ & $\begin{array}{l}\text { pegylated interferon alfa- } 2 \mathrm{~b}(1.0-1.5 \mu \mathrm{g} / \mathrm{kg} / \mathrm{week}) \\
\text { plus ribavirin }(800-1200 \mathrm{mg} / \text { day) for } 48 \text { weeks }\end{array}$ & $\begin{array}{l}\text { relapsers and } \\
\text { non-responders }\end{array}$ & $\begin{array}{l}31 \% \\
\text { (non-responder: } 5 \%)\end{array}$ & [25] \\
\hline Krawitt et al., 2005 & 24 & $\begin{array}{l}\text { pegylated interferon alfa- } 2 \mathrm{~b}(100-150 \mu \mathrm{g} / \text { week) plus } \\
\text { ribavirin ( } 1000 \mathrm{mg} / \text { day) for } 48 \text { weeks }\end{array}$ & $\begin{array}{l}\text { relapsers }(n=17) \text { and } \\
\text { non-responder }(n=7)\end{array}$ & $\begin{array}{l}\text { relapsers:59\%; } \\
\text { non-responders:57\% }\end{array}$ & [26] \\
\hline Basso et al.,2007. & $28^{*}$ & $\begin{array}{l}\text { pegylated interferon alfa- } 2 \mathrm{~b}(1 \mu \mathrm{g} / \mathrm{kg} / \mathrm{week}) \text { plus } \\
\text { ribavirin }(800-1200 \mathrm{mg} / \text { day) for } 24 \text { weeks }\end{array}$ & relapsers & $78.6 \%$ & [23] \\
\hline Jensen et al.,2009 & 7 & $\begin{array}{l}\text { pegylated interferon alfa-2a ( } 360 \mu \mathrm{g} / \mathrm{wk} \text { for } 12 \\
\text { weeks, then } 180 \mu \mathrm{g} / \mathrm{wk} \text { for } 36-60 \mathrm{weeks} \text { or } 180 \mu \mathrm{g} / \mathrm{wk} \\
\text { for } 48-72 \text { weeks) plus ribavirin }(800-1200 \mathrm{mg} / \mathrm{day})\end{array}$ & Non-responders & $\mathrm{N} / \mathrm{A}$ & [27] \\
\hline Poynard et al., 2009 & 75 & $\begin{array}{l}\text { peginterferon alfa- } 2 \mathrm{~b}(1.5 \mu \mathrm{g} / \mathrm{kg} / \mathrm{wk}) \text { plus weight-based } \\
\text { ribavirin }(800-1400 \mathrm{mg} / \mathrm{day}) \text {; treatment duration varied } \\
\text { according to week } 12 \text { response }\end{array}$ & $\begin{array}{l}\text { relapsers and } \\
\text { non-responders with } \\
\text { METAVIR score } \geq 2\end{array}$ & $\begin{array}{l}\text { relapsers:61\%; } \\
\text { non-responders: } 46 \%\end{array}$ & [28] \\
\hline Oze et al.,2011 & 18 & $\begin{array}{l}\text { pegylated interferon alfa- } 2 \mathrm{a}(180 \mu \mathrm{g} / \text { week }) \text { or alfa- } 2 \mathrm{~b} \\
(1.5 \mu \mathrm{g} / \mathrm{kg} / \text { week) plus ribavirin }(800-1200 \mathrm{mg} / \text { day }) \\
\text { for } 24 \text { weeks }\end{array}$ & $\begin{array}{l}\text { relapsers }(n=17) \text { and non- } \\
\text { responder }(n=1)\end{array}$ & $56 \%$ & [22] \\
\hline
\end{tabular}

Note: *including hepatitis $C$ virus genotype 2 and 3

doi:10.1371/journal.pone.0058882.t006

of IL-28B on the retreatment of HCV-2 infection has never been explored. We have demonstrated that IL-28B genetic variants would not determine either early viral kinetics or final treatment outcome in HCV-2 treatment-experienced patients. On the other hand, better on-treatment responses might be associated with a higher SVR rate. The achievement of a RVR has been suggested to be the most important factor predictive for an SVR regardless of host IL-28B genetic variants in HCV-1 infection [10,11] and is the most critical factor for $\mathrm{HCV}-2$ naive patients [5]. However, the SVR rate was not significantly different in patients with or without a RVR, and the achievement of an EVR was more accurate for retreated patients. The limited number of cases might partly account for the results in this study. However, it should be noted that viral elements to interferon responsiveness [34], as well as the host-virus interaction, might have been altered in the treatment experienced patients. The viral kinetics of interferon-based therapy in treatment experienced patients might be different from treatment-naïve patients. Whether the week 12 rather than week 4 responsiveness is a better surrogate for predicting an SVR for this special population deserves further investigation.[27,28] One limitation of this current study includes the limited number of

\section{References}

1. Yang JF, Lin CI, Huang JF, Dai CY, Lin WY, et al. (2010) Viral hepatitis infections in southern Taiwan: a multicenter community-based study. Kaohsiung J Med Sci 26: 461-469.

2. HuangJF, Yu ML, Lee CM, Dai CY, Hou NJ, et al. (2007) Sustained virological response to interferon reduces cirrhosis in chronic hepatitis C: a 1,386-patient study from Taiwan. Aliment Pharmacol Ther 25: 1029-1037.

3. Yu ML, Lin SM, Chuang WL, Dai CY, Wang JH, et al. (2006) A sustained virological response to interferon or interferon/ribavirin reduces hepatocellular carcinoma and improves survival in chronic hepatitis $\mathrm{C}$ : a nationwide, multicentre study in Taiwan. Antivir Ther 11: 985-994.

4. Ghany MG, Nelson DR, Strader DB, Thomas DL, Seeff LB (2011) An update on treatment of genotype 1 chronic hepatitis $\mathrm{C}$ virus infection: 2011 practice guideline by the American Association for the Study of Liver Diseases. Hepatology 54: 1433-1444.

5. Yu ML, Dai CY, Huang JF, Hou NJ, Lee LP, et al. (2007) A randomised study of peginterferon and ribavirin for 16 versus 24 weeks in patients with genotype 2 chronic hepatitis C. Gut 56: 553-559.

6. Mangia A, Santoro R, Minerva N, Ricci GL, Carretta V, et al. (2005) Peginterferon alfa-2b and ribavirin for 12 vs. 24 weeks in HCV genotype 2 or 3 . N Engl J Med 352: 2609-2617. cases, which render our findings less conclusive, particularly for the previous non-responders. Furthermore, our results have not been validated in other ethnic groups with different IL-28B genotypes. However, the role of IL-28B genetic testing was fully explored in the current study, and the satisfactory outcomes with peginterferon/ribavirin in patients who relapsed raised the issue of the cost-effectiveness of DAAs, which would be especially important in areas where HCV-2 infection is endemic. [1,21]

In conclusion, peginterferon/ribavirin is effective in the retreatment of HCV-2 relapsers, particularly among those who achieved an EVR. Host IL-28B genetic variants might play a minimal role in HCV-2 treatment-experienced patients. The role of DAAs in interferon-resistant HCV-2 patients awaits further elucidation.

\section{Author Contributions}

Acquisition of data: CFH CIH MLY MYH JFH CYD ZYL SCG LYW. Approval of the final version of the manuscript: MLY CYD. Conceived and designed the experiments: MLY CFH WLC CYD. Analyzed the data: CFH JFH CYD WLG MLY. Contributed reagents/materials/analysis tools: SHJ YCL. Wrote the paper: CFH MLY JFH WLC CYD.

7. Huang CF, Yang JF, Huang JF, Dai CY, Chiu CF, et al. (2010) Early identification of achieving a sustained virological response in chronic hepatitis $\mathrm{C}$ patients without a rapid virological response. J Gastroenterol Hepatol 25: 758765.

8. Di Bisceglie AM, Shiffman ML, Everson GT, Lindsay KL, Everhart JE, et al. (2008) Prolonged therapy of advanced chronic hepatitis C with low-dose peginterferon. N Engl J Med 359: 2429-2441.

9. Liu CH, Liang CC, Liu CJ, Tseng TC, Lin CL, et al. (2012) Interleukin 28B genetic polymorphisms and viral factors help identify hepatitis $\mathrm{C}$ virus genotype 1 patients who benefit from 24 week of peginterferon plus ribavirin therapy. Antivir Ther: in press.

10. Huang CF, Huang JF, Yang JF, Hsieh MY, Lin ZY, et al. (2012) Interleukin-28B genetic variants in identification of hepatitis $\mathrm{C}$ virus genotype 1 patients responding to 24 weeks peginterferon/ribavirin. J Hepatol 56: 34-40.

11. Huang CF, Yeh ML, Huang JF, Yang JF, Hsieh MY, et al. (2012) Host interleukin-28B genetic variants versus viral kinetics in determining responses to standard-of-care for Asians with hepatitis C genotype 1 Antiviral Res 93: 239 244. 
12. Thompson AJ, McHutchison JG (2012) Will IL28B polymorphism remain relevant in the era of direct-acting antiviral agents for hepatitis $\mathrm{C}$ virus? Hepatology 56: 373-381.

13. Yu ML, Huang CF, Huang JF, Chang NC, Yang JF, et al. (2011) Role of interleukin-28B polymorphisms in the treatment of hepatitis $\mathrm{C}$ virus genotype 2 infection in Asian patients. Hepatology 53: 7-13.

14. Sarrazin C, Susser S, Doehring A, Lange CM, Muller T, et al. (2011) Importance of IL28B gene polymorphisms in hepatitis C virus genotype 2 and 3 infected patients. J Hepatol 54: 415-421.

15. Mangia A, Thompson AJ, Santoro R, Piazzolla V, Tillmann HL, et al. (2010) An IL28B polymorphism determines treatment response of hepatitis $\mathrm{C}$ virus genotype 2 or 3 patients who do not achieve a rapid virologic response. Gastroenterology.139: 821- 827, 827 e821.

16. Schreiber J, Moreno G, Garcia BG, Louvet A, Trepo E, et al. (2012) Metaanalysis: the impact of IL28B polymorphisms on rapid and sustained virological response in HCV-2 and -3 patients. Aliment Pharmacol Ther 36: 353-362.

17. Vermehren J, Yu ML, Monto A, Yao JD, Anderson C, et al. (2011) Multi-center evaluation of the Abbott RealTime $\mathrm{HCV}$ assay for monitoring patients undergoing antiviral therapy for chronic hepatitis C. J Clin Virol 52: 133-137.

18. Martinez SM, Fernandez-Varo G, Gonzalez P, Sampson E, Bruguera M, et al. (2011) Assessment of liver fibrosis before and after antiviral therapy by different serum marker panels in patients with chronic hepatitis C. Aliment Pharmacol Ther 33: 138-148.

19. Craxi A (2011) EASL Clinical Practice Guidelines: Management of hepatitis C virus infection. J Hepatol 55: 245-264.

20. Omata M (2012) APASL consensus statements and management algorithms for hepatitis $\mathrm{C}$ virus infection. Hepatol International.in press.

21. Yu ML, Chuang WL (2009) Treatment of chronic hepatitis C in Asia: when East meets West. J Gastroenterol Hepatol 24: 336-345.

22. Oze T, Hiramatsu N, Yakushijin T, Mochizuki K, Oshita M, et al. (2011) Efficacy of re-treatment with pegylated interferon plus ribavirin combination therapy for patients with chronic hepatitis C in Japan. J Gastroenterol 46: 10311037.

23. Basso M, Torre F, Grasso A, Percario G, Azzola E, et al. (2007) Pegylated interferon and ribavirin in re-treatment of responder-relapser HCV patients. Dig Liver Dis 39: $47-51$.
24. Shiffman ML, Di Bisceglie AM, Lindsay KL, Morishima C, Wright EC, et al. (2004) Peginterferon alfa-2a and ribavirin in patients with chronic hepatitis C who have failed prior treatment. Gastroenterology .126: 1015-1023; discussion 1947.

25. Jacobson IM, Gonzalez SA, Ahmed F, Lebovics E, Min AD, et al. (2005) A randomized trial of pegylated interferon alpha-2b plus ribavirin in the retreatment of chronic hepatitis C. Am J Gastroenterol 100: 2453-2462.

26. Krawitt EL, Ashikaga T, Gordon SR, Ferrentino N, Ray MA, et al. (2005) Peginterferon alfa-2b and ribavirin for treatment-refractory chronic hepatitis $\mathrm{C}$. J Hepatol 43: 243-249.

27. Jensen DM, Marcellin P, Freilich B, Andreone P, Di Bisceglie A, et al. (2009) Re-treatment of patients with chronic hepatitis $\mathrm{C}$ who do not respond to peginterferon-alpha2b: a randomized trial. Ann Intern Med 150: 528-540.

28. Poynard T, Colombo M, Bruix J, Schiff E, Terg R, et al. (2009) Peginterferon alfa- $2 \mathrm{~b}$ and ribavirin: effective in patients with hepatitis $\mathrm{C}$ who failed interferon alfa/ribavirin therapy. Gastroenterology.136: 1618-1628e1612.

29. Yu ML, Huang CF, Dai CY, Huang JF, Chuang WL (2007) Long-term effects of interferon-based therapy for chronic hepatitis C. Oncology 72 Suppl 1: 16-23.

30. Singal AG, Waljee AK, Shiffman M, Bacon BR, Schoenfeld PS (2010) Metaanalysis: re-treatment of genotype I hepatitis $\mathrm{C}$ nonresponders and relapsers after failing interferon and ribavirin combination therapy. Aliment Pharmacol Ther 32: 969-983.

31. Foster GR, Hezode C, Bronowicki JP, Carosi G, Weiland O, et al. (2011) Telaprevir alone or with peginterferon and ribavirin reduces HCV RNA in patients with chronic genotype 2 but not genotype 3 infections. Gastroenterology.141:881- 889 e881.

32. Mangia A, Mottola L (2012) What's new in HCV genotype 2 treatment. Liver Int.32 Suppl 1: 135-140

33. Liu S, Cipriano LE, Holodniy M, Owens DK, Goldhaber-Fiebert JD (2012) New protease inhibitors for the treatment of chronic hepatitis C: a costeffectiveness analysis. Ann Intern Med 156: 279-290.

34. Kozuka R, Enomoto M, Hai H, Ogawa T, Nakaya M, et al. (2012) Changes in sequences of core region, interferon sensitivity-determining region and interferon and ribavirin resistance-determining region of hepatitis $\mathrm{C}$ virus genotype 1 during interferon-alpha and ribavirin therapy, and efficacy of retreatment. Hepatol Res. In press. 